\title{
Lines in Substitution for a Eulogy FOR A DEAD ELDER
}

Living, you were doubtful of your soul. Even the many cups of fatty tissue that composed you, you said, would readily melt. And can what's so unstable be really real, you asked.

A kind of flirtation. But your children hadn't any answer, then or now.

Only ideas are finally real, you said. Icelocked and blazing with cold, inhabiting an absent world.

You were quick, gentle, razorish, kind, sometimes mean, yes, but witty. Wit is an obligation to our friends, a common courtesy-keeps them at a distance. And in the end your face was stitched with wit as with fine silver wires, cloisonné work so precise it hurts to look. Colors baked into the enamel, not born with it.

I loved you. But this, you explained, was only my idea of you. And in time others competed with their ideas, elbowed me aside. I think I didn't mind. Though you'd told us all, Truth weakly spoken becomes a lie.

And, still, you died. And how freely your children breathe, now. How small the terms of our reconciliation. 